\title{
KRZYŻ ARMEŃSKI - KHATCHKAR
}

Uczeni twierdzą niemal jednogłośnie, że źródeł powstania formy krzyża armeńskiego zwanego khatchkarem (czyt. chaczkar) należy szukać w szczególnie mocno zakorzenionym w Armenii - kulcie Krzyża Świętego ${ }^{1}$. Odkrycie Drzewa Krzyża Świętego przez Helenę, matkę Konstantyna na pocz. IV wie$\mathrm{ku}$, wybudowanie kompleksu na Golgocie i wzniesienie tam bogato zdobionego krzyża, rozpoczęło długi okres intensywnego rozwoju kultu Krzyża na wszystkich terenach Cesarstwa Rzymskiego, a także wzrost pielgrzymek do Jerozolimy $^{2}$. Wiele lat po śmierci Heleny rozpowszechniła się legenda o tym, jak odkryła ona Drzewo Krzyża. Ustanowiono także 14 września święto „Odnalezienia Krzyża”. Ceremonie powstałe wokół Drzewa Krzyża ukształtowały roczny cykl świąt. Opisy tych ceremonii, choć mało precyzyjne, znajdują się już w dzienniku Egerii ${ }^{3}$. Bardziej dokładne można znaleźć w Armeńskim Lekcjonarzu datowanym na ok. 460 rok $^{4}$. W następstwie wyżej opisanych

${ }^{1}$ Por. H. Richardson, The Concept of the High Cross, w: P. Ní Chatháin - M. Richter (eds.), Ireland and Europe. The Early Church, Stuttgart 1984, 129-131; H. Richardson, Observations on Christian art in Early Ireland, Georgia and Armenia, w: M. Ryan (ed.) Ireland and Insular Art A.D. 500-1200, Dublin 1987, 136- 137; H. Richardson, The Jewelled Cross and its canopy, w: C. Bourke (ed.), From the Isles of the North. Early Medieval Art in Ireland and Britain, Belfast 1995,177-186; J.P. Mahé, Kościót armeński w latach 611-1066, w: Historia Chrześcijaństwa. Religia, kultura, polityka, red. G. Dagron - P. Riché - A. Vauchez, t. 4: Biskupi, mnisi i cesarze 610-1054, tłum. G. Majcher, Warszawa 1999, 391-392; А. Якобсон, Армянские хачкары, Ереван 1986, 92 (obszerne streszczenie w j. angielskim).

2 Por. E.D. Hunt, Holy Land Pilgrimage in the Later Roman Empire A.D. 316-460, Oxford 1982.

${ }^{3}$ Por. J. Wilkinson, Egeria's Travels to the Holy Land, Jerusalem and Warminster 1980, 3-12. Na temat kultu Drzewa Krzyża pisze w swej dysertacji M. Krasnodębska, The Origins of the cult Jerusalem, Constantinople, Rome, w: Studies in the Early Insular Iconography of the Cross, Dublin 1992, 9-15 (w maszynopisie).

${ }^{4}$ Por. A. Renoux, Le Lectionnaire de Jéruzalem en Arménie: le Casoc', I: Introduction et liste des manuscrites, PO 44, 421-551; M. Starowieyski, Słownik wczesnochrześcijańskiego piśmiennictwa Wschodu, (= SWPW), Warszawa 1999, 25; Wilkinson, Egeria's Travels to the Holy Land, 253 266; Krasnodębska, Studies in Early Insular Iconography, s. 12. 
wydarzeń wykształciły się w następnych stuleciach różne typy krzyży m.in.: etiopski, koptyjski, armeński i celtycki.

W Armenii kult Drzewa Krzyża rozprzestrzenił się szybko i znalazł odbicie w różnych dziedzinach życia. W V wieku ustanowiono trzy święta jerozolimskie obchodzone 14 września, 7 maja i w Wielki Piątek ${ }^{5}$. Pozostały także liczne w całym roku liturgicznym wspomnienia Krzyża Świętego, które znalazły odbicie we wspomnianym Lekcjonarzu. W V wieku powstał także Enkomion ku czci Świętego Krzyża przypisywany Dawidowi Anhaght, filozofowi, neoplatończykowi (470-550), kanonizowanemu przez kościół armeński. Jego tekst znany z licznych tłumaczeń stanowi paralelę do późniejszego hymnu ku czci relikwii Świętego Krzyża Wenancjusza Fortunata (530-609) ${ }^{6}$.

W tym samym czasie wraz $\mathrm{z}$ przyjęciem chrześcijaństwa pojawiły się w Armenii pierwsze krzyże. Kiedy zerwano z dotychczasowym systemem wierzeń, pierwszymi poczynaniami św. Grzegorza Oświeciciela, ewangelizatora Armenii, była budowa kościołów i kaplic, o czym mówią liczne wzmianki u Agatangelosa (151) ${ }^{7}$. Zgodnie też z jego przekazem, Grzegorz podróżując po kraju, erygował drewniane krzyże i filary w kaplicach męczenników i znaczył skrzyżowania dróg. O pierwszych krzyżach mówi także słynna wizja Grzegorza, w której widział on cztery wielkie kolumny z krzyżami na miejscu kapitelu. Trzy znaczyły miejsce upamiętniające męczeństwo Rypsymy, Gajany i Mariny, czwarty, najwyższy miał znaczyć katedrę w Eczmiadzynie ${ }^{8}$. Pierwsze krzyże stawiano także w miejscach pogańskich sanktuariów jako symbole zwycięstwa. Zdaniem niektórych uczonych, pierwsze krzyże pełniły również rolę upamiętniającą ważne wydarzenia, a także umieszczano je na drogach „by towarzyszyły podróżnym i służyły jako rodzaj talizmanu",.

\footnotetext{
${ }^{5}$ Por. Mahé, Kościót armeński, 392.
}

${ }^{6} \mathrm{Na}$ temat Dawida Anhaght por. Starowieyski, SWPW 49-50; o jego Enkomionie ku czci Krzyża Świętego, por. H. Richardson, The Jewelled Cross and its canopy, w: C. Bourke (ed.), From the Isles of the North. Early Medieval Art in Ireland and Britain, Belfast 1995, 181; Hymn (II 7) „Vexilla regis prodeunt”, PL 88, 95-96 lub: S. Walpole, Early Latin Hymn, Cambridge 1922 (Hildesheim 1966), 173-177, przekład polski: Muza chrześcijańska, t. 2: Poezja łacinska starożytna i średniowieczna, OŻ X, Kraków 1992, 147-148; inny hymn ku czci Krzyża Świętego, tamże, 150151. Hymn „Vexilla regis prodeunt” napisał Fortunat w 569 r. świętując przybycie relikwii Świętego Krzyża do klasztoru pod wezwaniem Świętego Krzyża, które dzięki staraniom królowej Radegundy przybyły do Poitiers, zob. G. Henderson, Wczesne średniowiecze, tłum. P. Paszkiewicz, Warszawa 1984, 232.

7 Por. D. Próchniak, Początki Kościoła armeniskiego, ,Zeszyty Naukowe Uniwersytetu Jagiellońskiego. Studia Religiologica” 32 (1999) 44; tenże, Przedchrześcijańska sakralna architektura Armenii. Próba rekonstrukcji wświetle źródet materialnych i przekazów literackich, RH 31 (1983) z. 4, 28.

${ }^{8}$ Por. Richardson, Observations on the Christian art, s. 7. O Rypsymie por. M. Starowieyski, Od legendy do historii. Święte zatożycielki Kościołów Gruzji i Armenii, SACh 14 (1999) 20-23; zob. niżej (s. 459-477): Męczeństwo św. Rypsymy.

${ }^{9}$ N. Stepanian - A. Tchakmaktchian (eds.), L'art decorative de l'Arménie medievale, Leningrad 1971, 34; Якобсон, Армянские хачкары, dz. суt., s. 92. 
Bezpośrednią przyczynę narodzin khatchkara, uczeni dostrzegają w fakcie uwolnienia w 629 roku przez cesarza Herakliusza Prawdziwego Krzyża, „uprowadzonego w niewolę” przez Chosroesa II po zdobyciu Jerozolimy. Wówczas odbudowano kompleks na Golgocie, a relikwie Krzyża przeniesiono przed 638 rokiem do Hagia Sofia w Konstantynopolu ${ }^{10}$. W Armenii na cześć uwolnienia Krzyża wzbogacono liturgię dawnego święta obchodzonego 14 września, utrwalając na kilkaset lat pamięć o tym wydarzeniu ${ }^{11}$. Święto to było bardzo znane na Wschodzie od czasów papieża Sergiusza I (687-701). Echa uwolnienia Krzyża przez Herakliusza znajdziemy w architekturze Armenii, w legendach i relacjach historycznych, a także właśnie w rozpowszechnieniu krzyża i powstaniu khatchkara ${ }^{12}$.

Armenia przyjęła chrześcijaństwo z Kapadocji i Syrii, a z Gruzją była w ścisłych kulturowych związkach ${ }^{13}$. Może właśnie dlatego w Armenii, Kapadocji i Gruzji spotykana jest forma krzyża, która legła u podłoża powstania klasycznego khatchkara. Poprzednikami khatchkarów były powstałe w VI i VII wieku okrągłe lub wieloboczne filary, zwieńczone przez monumentalne krzyże. Znaleziono je w Garnahivit, Agarak, Arich, Talin, Mren i Dwinie (fig. $1)^{14}$. Powierzchnię filarów dekorowały gałęzie winorośli z „,bujającymi się kiśćmi winogron". Niekiedy były one obramowane kolumnami, które nadawały im architektoniczny efekt. Krzyże zwieńczające filary były dużych rozmiarów i dekorowane z obu stron symetrycznie rozmieszczonymi szerokimi palmetowymi liśćmi „Z wdziękiem wyginającymi się ku poprzecznemu ramieniu krzyża”"15.

W tym czasie podobne krzyże powstawały w Gruzji i Kapadocji. W Gruzji już w IV wieku św. Nino stawiała krzyże na górach. W 2. poł. VI wieku powstał

${ }^{10}$ Por. A. Florow, Les Reliquaries de la Vraie Croix, Paris 1965, 188. Opis ceremonii przy Drzewie Krzyża w Hagia Sophia przetrwał tylko w dwóch przekazach: De locis sanctis Adomnana (679-704), CCL 175, 183-234 i De locis sanctis Bedy (672-735), CCL 175, 251-280, który oparł się na dziele Adomnana, zob. M. Krasnodębska, Studies in the Early Insular Iconography, s. 14. Hymn Fortunata śpiewano także w czasie ceremonii Wielkiego Czwartku na Lateranie, gdzie przechowywano relikwie Świętego Krzyża, por. M. Andrieu, Les Ordines Romani du Haut Moyen Age, vol. 2, Louvain 1971, 38-51.

${ }^{11}$ O powrocie Prawdziwego Krzyża, zob. B. Flusin, Saint Anastase le Perse et l'histoire de la Palestine au début du V-VII siècle, II, Paris 1992, 295-309.

${ }^{12}$ Istnieje inskrypcja i płaskorzeźba upamiętniająca zwrot Drzewa Krzyża Świętego, a legendy głoszą, że wytrysnęło cudowne źródło ze zbocza góry, tam, gdzie Herakliusz ukrył krzyż podczas bitwy z Persami. por. Mahé, Kościót armeński, s. 392, przypis 82. O historii relikwii Drzewa Krzyża, zob. R.W. Thomson, The Anonymous Story-Teller (Also known as Pseudo-Sapuh), REArm NS 21 (1988/89) 173-232.

${ }^{13}$ Ewangelizator Armenii Grzegorz Oświeciciel przybył z Cezarei Kapadockiej. O początkach chrześcijaństwa w Armenii, por. D. Próchniak, „Historia Armenii” Agatangelosa jako źródto do poznania chrześcijańskich dziejów Armenii, VoxP 3 (1983) z. 4, 160-175; tenże, Poczq̨tki Kościoła armeńskiego, s. 33-46; Starowieyski, Od legendy do historii, s. 20-31.

${ }^{14}$ Рог. Якобсон, Армянские хачкары, s. 93.

15 Tamże. 
nad krzyżem erygowany przez nią kościół, zwany Djvari lub Święty Krzyż ${ }^{16}$. H. Richardson wymienia stele $z$ Khandisi, Bolnisi, Lamazi-Gora oraz grupę z Svanetii, których styl zbliżony jest do dzieł wywodzących się ze szkoły rzeźbiarskiej znajdującej się w północnej Armenii w prowincji Lori ${ }^{17}$. Podobne paralele znajdziemy w malarstwie ściennym kościołów Kapadocji. Nicole Thierry charakteryzując szkołę malarską w Kapadocji poświadcza także szczególną popularność opisywanego tu motywu krzyża, którego formę spotykamy od VI do XI wieku, zarówno na ścianach kościołów, jak i na powierzchni ich kopuł (fig. 2). Prócz przedstawień świętych, Dziewicy Maryi i Chrystusa, krzyż ten, jako wyraz szczególnego kultu był tam bardzo popularnym motywem ${ }^{18}$. Również N. Teteriatnikov, omawiając malowidła kaplicy św. Bazylego w Kapadocji, datowane na pocz. X wieku stwierdza, iż program dekoracyjny kaplicy oparty został na liturgii „Wywyższenia Krzyża”19. I tu pojawiają się krzyże flankowane palmetami i małymi serduszkami (fig. 3). Obok jednego z takich krzyży znajduje się nawet inskrypcja będąca inwokacją do Krzyża Świętego ${ }^{20}$.

Do X wieku, wykształcony w VI i VII wieku typ krzyża został zamieniony na „wysokim stylobacie"21. Zdaniem znawców jest to konsekwencją faktu, iż khatchkar od początku miał ,,architektoniczną naturę”, i był w istocie formą „małej architektury”22. Krzyże te były sytuowane pod półkolistą arkadą lub liście palmetowe tworzyły wokół nich kolistą otoczkę. Tendencja ta utrzymała się do XVII wieku. Zdaniem uczonych fakt ten był wynikiem wpływów wschodniej idei kosmicznego nieba, niebiańskiej sfery, firmamentu i nawiązuje do kopuły świątynnej ( rys. 4$)^{23}$.

${ }^{16}$ Por. Richardson, The Concept of the High Cross, s. 133. O początkach chrześcijaństwa w Gruzji i o świętej Nino por. P. Peeters, Les débuts du christianisme en Géorgie d'après les sources hagiographiques, AnBol 50 (1932) 5-58; M. Tarchnišvili, Sources arménogéorgiens de l'histoire arménienne, „Le Muséon” 69 (1947) 29-50. O wczesnej literaturze patrystycznej w Gruzji i Lekcjonarzu Jerozolimskim, wzorowanym na Lekcjonarzu Armeńskim, zob. Starowieyski, SWPW 76-84.

17 Por. Richardson, The Jewelled cross, s. 182-184 (Crosses in Georgia).

18 Por. N. Thierry, Une école de peinture gréco-orientale du haut Moyen Age en Cappadoce, w: Byzantine East, Latin West. Art-Historical Studies in Honour of Kurt Weitzmann, eds. Ch. Moss K. Kiefer, Princeton 1995, 299-308; J. Lafontaine - Dosogne, Pour une problématique à l'époque iconoclaste, „Dumbarton Oaks Papers” 41 (1987) 321-337; P. Amandry, Objects orientaux en Grèce et en Italie aux VIII et VII siècles av. J-C., „Syria” 35 (1958) 73-109; N. Thierry, Matériaux nouveaux en Cappadoce, „Byzantion” 54 (1984) 339-350; taż, La croix en Cappadoce. Typologie et valeur representative, w: La site monastique copte des Kellia. Actes du Colloque de Genève (13-15 août 1984), Genève 1989, 197-212, pls. I-VIII.

19 Por. N. Teteriatnikov, The frescoes of the Chapel of St. Basil in Cappadocia: their Date and Context reconsidered, „Cahiers Archéologiques” 40 (1992) 99-114.

${ }^{20}$ Por. G. de Jerphanion, Les églises rupestres de Cappadoce, II, Paris 1936, 107-108.

21 Por. Якобсон, Армянские хачкары, s. 92; Richardson, Observations on Christian art, s. 132

22 Por. Якобсон, Армянские хачкары, s. 92.

${ }^{23}$ Por. tamże, s. 93; Richardson, The Concept of the High Cross, s. 131. 
W X wieku powstały w pełni wykształcone khatchkary, które rozpowszechniły się między XI-XIII wiekiem. Łączone są m.in. z gawitami, salami przylegającymi zwykle do zachodniej fasady kościoła, które służyły celom klasztoru, a także celom świeckim, były też miejscami pochówku. W ściany gawitów wmurowywano często khatchkary ${ }^{24}$. S. Barkhoudarian odczytał wiele inskrypcji na studiowanych przez siebie khatchkarach i konstatuje, że były one wystawiane jako upamiętnienie: zwycięstwa, fundacji miasta, konsekracji kościoła, znak rozpoznawczy własności, znak graniczny lub stela nagrobna ${ }^{25}$. Od $\mathrm{X}$ wieku kompozycja khatchkara posiadała stałą formułę, która przetrwała w następnych stuleciach. Krzyże umieszczane były pod półkolistym łukiem lub portalem z bocznymi półkolumnami. Pod krzyżem horyzontalnie i symetrycznie rozpościerały się cztero-, pięcio-, siedmio- lub dziesięciolistne palmety. Nad krzyżami lub pod nimi zwisały kiście winnego grona. Od XI wieku następuje tendencja do „surowej grafiki”, geometryzacji i większej dekoracyjności motywów roślinnych. Wzmocniono także architektoniczną otoczkę krzyża. Poniżej krzyża pojawia się wówczas motyw schodów (o czterech stopniach) lub ornamentalnie oddany motyw kuli. Od XII wieku khatchkary weszly w swój kwitnący okres, były stawiane wszędzie i nie tylko z powodów religijnych, ale także politycznych i ekonomicznych (fig. 5,6,7,) ${ }^{26}$. Od XIII wieku pojawiają się wyizolowane sceny biblijne umieszczone w wolnych powierzchniach między ramionami krzyża oraz scena Ukrzyżowania ${ }^{27}$. Tradycje ikonograficzne powstałe w okresie od X-XIII wieku przetrwały do XVII wieku.

Każdy kraj rozwinął swoją formę krzyża do świętowania jego tryumfu. W tym czasie także Irlandia była związana ze Wschodem. Irlandzcy uczeni wskazują na związki Irlandii z Armenią, m.in. na podobieństwa, przynajmniej ideowe, między krzyżami celtyckimi i khatchkarami ${ }^{28}$. Tak jak armeńskie, również krzyże celtyckie wywodzi Richardson z kultu krzyża wzniesionego na Golgocie oraz idei Drzewa Życia ${ }^{29}$. Irlandczycy znali Grób Pański na Golgocie i wygląd krzyża z De locis sanctis autorstwa Adomnana (VII w.), który

${ }^{24}$ Por. P. Trzeciak, Sztuka dawnej Armenii, w: Sztuka Swiata, Warszawa 1993, 187-211.

${ }^{25}$ Por. S. Barkhoudarian, Les architects et tailleurs de pierre de l'Arménie médiévale, Erevan $1963,122-134$.

${ }^{26}$ Рог. Якобсон, Армянские хачкары, s. 94-95.

27 Por. tamże, ryc. 59, 60, 61, 62, 87.

28 Por. Richardson, Observations on Christian art, s. 129. Wśród nielicznych jak dotąd bezpośrednich dowodów na związki Irlandii z Armenią należy wymienić obecność imion armeńskich w litanii pochodzącej z IX wieku, por. C. Plummer, Irish litanies, vol. 62, London 1925, 56-7; F. Henry wykazała także wpływ Armenii na architekturę kościoła w Rahan (hr. Offaly), zob. F. Henry, Irish art in the Early Christian period, London 1940, 94-97. Natomiast fragment z Táin Bó Cúalnge - starej irlandzkiej opowieści, znajdującej się w Book of Leinster, datowanej na r. 1290, mówi, że Fergus mac Róig - jak opowiada on herosowi Cú Chulainnowi - ,podróżował tak daleko, jak góry Armenii" (Sléibe Aremnie), por. C. O'Rahilly, Táin Bó Cualnge, Dublin 1967, 35. O duchowych związkach Armenii i Irlandii por. R. Bulas, Symbole pogańskie, 167, 212-214. 
spsał relacje z podróży na Wschód i do Ziemi Świętej podróżnika Arculfa ${ }^{30}$. W Irlandii odbicie kultu Krzyża znajdziemy także w apokryfach np. w Saltair na Rann, gdzie znajduje się piękny poemat Król drzewa Życia ${ }^{31}$. Po 750 roku powstał także na Wyspach Brytyjskich anglosaksoński poemat Elene o św. Helenie znajdującej Prawdziwy Krzyż, wzorowany na hymnie Wenancjusza Fortunata. Hymn ten znalazł także odbicie w apokryfie Odnalezienie Prawdziwego Krzyża $a^{32}$. O kulcie Drzewa Krzyża na Wyspach świadczy także zachowany we fragmentach The Dream of the Rood (Sen o Drzewie), runiczna inskrypcja w nostumbryjskim dialekcie języka staroangielskiego, zachowana na krzyżu z Ruthwell (ok. 800) ${ }^{33}$. Inskrypcja ta, która stanowi odniesienie do liturgii Wielkiego Piątku, mówi o tym, jak „krzyż cierpi razem z Chrystusem, jest poprzybijany gwoździami i cały zbroczony krwią" ${ }^{34}$.

H. Richardson, zwolenniczka tezy o ideowych, a także częściowo formalnych związkach krzyży celtyckich powstałych między VIII a XI wiekiem w Irlandii, a krzyżami khatchkarami, uważa, że również krzyże celtyckie powstały jako wynik pielgrzymek do Jerozolimy i nawiązanie do krzyża na Golgocie, do skeumorphos i samej budowli Grobu Świętego ${ }^{35}$. Wskazując na paralele między krzyżami celtyckimi a formą reliefowych krzyży Gruzji i armeńskich khatchkarów, widzi je głównie w schodkowej formie bazy czy

${ }^{29}$ Por. Richardson, The Jewelled Cross, 187; N. Stepanian - A. Tchakmaktchian (eds.), L'art decorative de l'Armenie, s. 35 i 37.

${ }^{30}$ Por. D. Meehan (ed.), Adomnán's „De locis sanctis”, Dublin 1958, 49; T. O'Loughlin, The Exegetical Purpose of Adamnan's De locis sanctis, CMCS 24 (1992) 37-55; R. H. Storch, The Trophy and the Cross: Pagan and Christian Symbolism in the Fourth and Fifth Centuries, „Byzantion" 40 (1950) 105-118.

${ }^{31}$ Por. Richardson, The Jewelled Cross, s. 187

32 Por. M. McNamara, The Apocrypha in the Irish Church, Dublin 1975, 78-79; V.C. Hull, The Invention of the Cross, ,Speculum” 3 (1928) 98-107; Richardson, Concept, 130; R.W. Hunt, Manuscript evidence for knowledge of the poems of Venantius Fortunatus in Late Anglo-Saxon England, ,Anglo-Saxon England” 8 (1979) 279-287.

${ }^{33}$ Poemat Dream of Rood istnieje w dwóch wersjach: wyryty na Ruthwell Cross oraz w ok. 150 linijkach zachowanych w późno X-wiecznej Vercelli Book, por. B.C. Raw, The Dream of the Rood and its connections with Early Christian art., ,Medium Aevum” 39 (1970) 239-256; R. Woolf, Doctrinal Influence on „, The Dream of Rood”, ,Medium Aevum” 27 (1958) 137-153. Na temat krzyża z Ruthwell, zob. także É. O'Carragáin, The Ruthwell Crucifixion Poem and its iconographic and liturgical contexts, „Peritia” 6-7 (1987-1988) 18-21; M. Schapiro, The Religious Meaning of the Ruthwell Cross, „Art Bulletin” 26 (1944) 232-245.

${ }^{34}$ Henderson, Wczesne średniowiecze, s. 238-239.

35 Por. Richardson, The Concept of the High Cross, 131. Małe modele kościołów lub tzw. Cap stone są jej zdaniem nawiązaniem do Grobu Świętego. O innej interpretacji Cap stone w kontekście krzyży celtyckich, por. R. Bulas, Symbole pogańskie na celtyckich krzyzach. Mity - symboleobrazy, Lublin 2002. Skeumorphos to metalowe okucia drewnianych krzyży, imitujące drogocenne kamienie zdobiące krzyż na Golgocie, zob. Richardson, The Concept of the High Cross, s. $127-$ 134; taż, Observations on Christian art, s. 129-137; H.M. Roe, The Irish High Cross: Morphology and Iconography, ,Journal of the Royal Society of Antiquaries of Ireland” 45 (1965) 213-226. 
w tematyce biblijnej steli z Odzun, z Haridij, które porównuje z anglosaksońskim krzyżem z Ruthwell ${ }^{36}$. Podobieństwa do wczesnych krzyży celtyckich, wykazuje - jej zdaniem - znajdująca się w północnej Armenii, w prowincji Lori, szkoła rzeźbiarska działająca w VI i VII wieku. Richardson konstatuje dalej, że [...] „kamienne krzyże są częścią dziedzictwa zarówno Irlandii jak Armenii. Mają one swoje indywidualne interpretacje i w obu przypadkach są kulturowym emblematem" 37 .

Symbolika omawianych tu krzyży ma wspólne źródło, oscyluje wokół kultu Drzewa Krzyża z Golgoty i idei Drzewa Życia. Pierwsze krzyże armeńskie były emblematem chrześcijaństwa, „symbolizowały abstrakcyjną naturę Boga chrześcijańskiego"38. W następnych stuleciach powstawała nowa idea Krzyża. Poprzez użycie symboli winorośli, motywu wyrastających z podłoża krzyża liści, a także motywów rozet i serc, tworzyła się koncepcja krzyża rozumianego jako mające moc odradzania - Drzewo Życia. Architektoniczna „natura” khatchkara sugeruje, że należy go odnieść do jakiejś budowli w sposób bezpośredni bądź symboliczny. Krzyż z półkolistym zwieńczeniem sugeruje, że nawiązano tu do budowli Anastazis i krzyża na Golgocie. Na tę formalną analogię nałożono interpretację duchową. Ikonografia khatchkarów mieści bowiem w sobie treści uniwersalne, które implikują: półkolista arkada i motyw kuli umieszczony u stóp wielu krzyży. Architektura khatchkara obrazuje wówczas kopułę niebiańską i kulę ziemską pomiędzy którymi rozpościera się Krzyż mający moc odradzania i dający nowe życie.

\section{ARMENIAN CROSS - KHATCHKAR}

\section{(Summary)}

The author presents early history of the Armenian crosses. The first impuls to rise the khatchkars were the following two factors: the discovery of the Crucifixion Cross by Constantine's mother Helena at the beginnings of $4^{\text {th }}$ century and recovery the Holy Cross by emperor Haraclius in 629 . As a result of first fact in the $5^{\text {th }}$ century a feast of the „Invention of the Cross” was introduced to the Church's calendar on the $14^{\text {th }}$ of September. The complex of buildings and jeweled Cross was erected on the site of Crucifixion on Golgota and the cult of the Holy Cross started. Khatchkars developed from cross monuments, originally wooden and later made of stone. In the $4^{\text {th }}$ century, they were erected on pillars or columns on the sites of ancient pagan

\footnotetext{
${ }^{36}$ Por. Richardson, Jewelled Cross, s. 184-185; taż, Observations on Christian art, s. 134.

37 Por. Richardson, Observation on Christian art, s. 130.

${ }^{38}$ Por. Stepanian - A. Tchakmatchian (eds.), L'art decorative de l'Arménie, s. 34.
} 
sanctuaries. Later from the $10^{\text {th }}$ century, the pillar or column was replaced by a high massive stylobate. The architecture dominated the khatchkar that had been from the very beginning a kind of a ,minor architecture”. From $11^{\text {th }}$ century khatchkars had vertical orientation of geometricized foliage, such crosses became especially popular in $12-13^{\text {th }}$ centuries, a period of flourishment. The khatchkars continued to be created in big numbers in the following period of $14-17^{\text {th }}$ centuries. H. Richardson, Irish scientist shows links between Armenian and Celtic Cross as they both commemorate Holy Cross on Golgota and refer to idea of Tree of Life. The author states: khatchkar symbolize Cross which has the power of regeneration and gives a new life. 


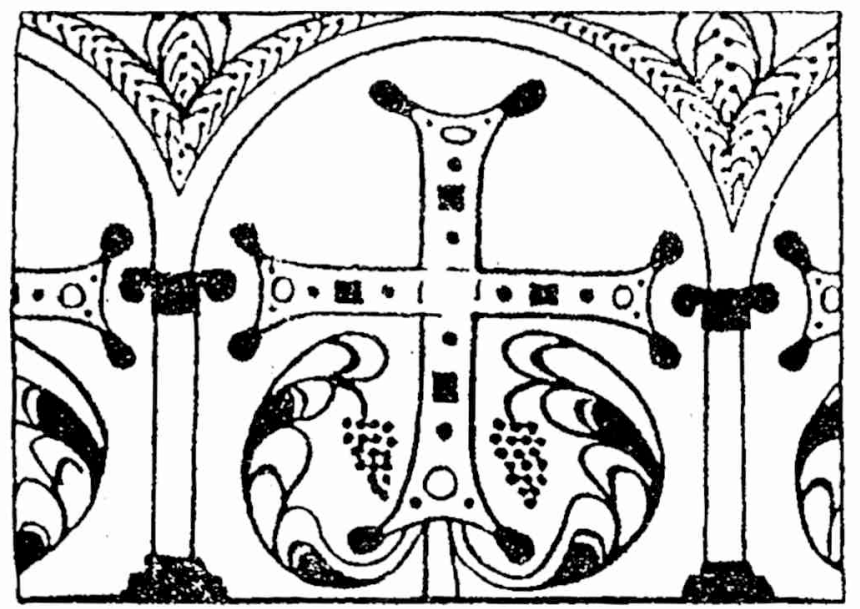

fig. 2. Nicétas, Transkaukazie, $\mathrm{X}$ wiek, według: $\mathrm{N}$. Thierry, Une école de peinture gréco-orientale, Schéma 3a.

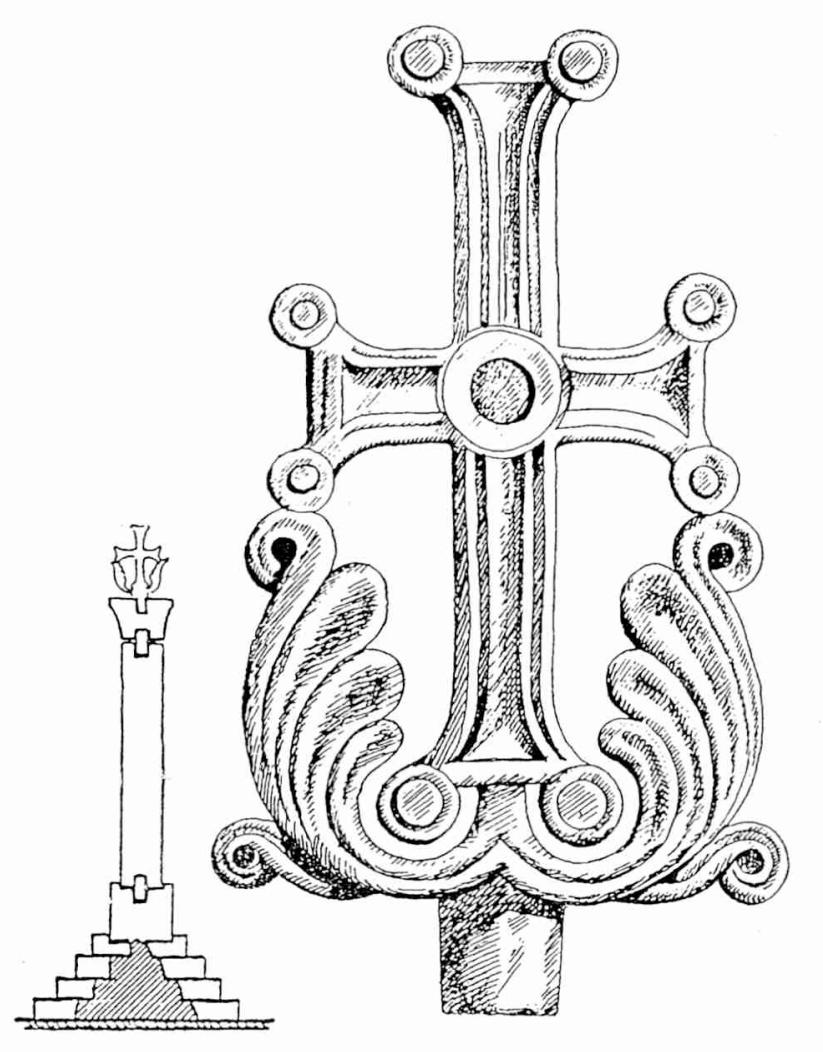

fig. 1. Dvin, Armenia, VI wiek, według: A. L. Jakobcon, Armenian Cross, ryc. 3 . 


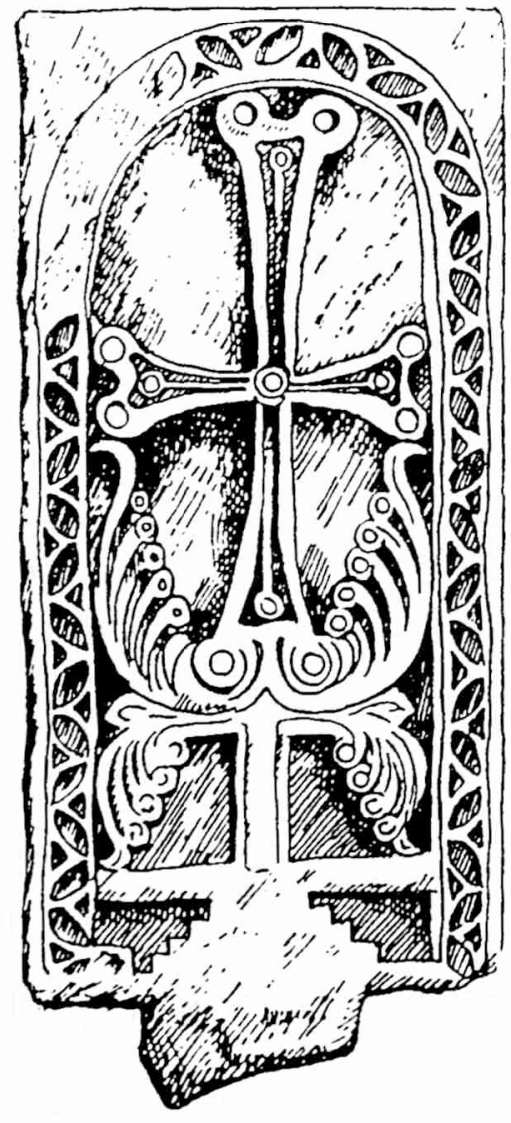

fig. 4. Armenia, X wiek, wedtug: A. L. Jakobcon, Arme nian cross, ryc. 4.

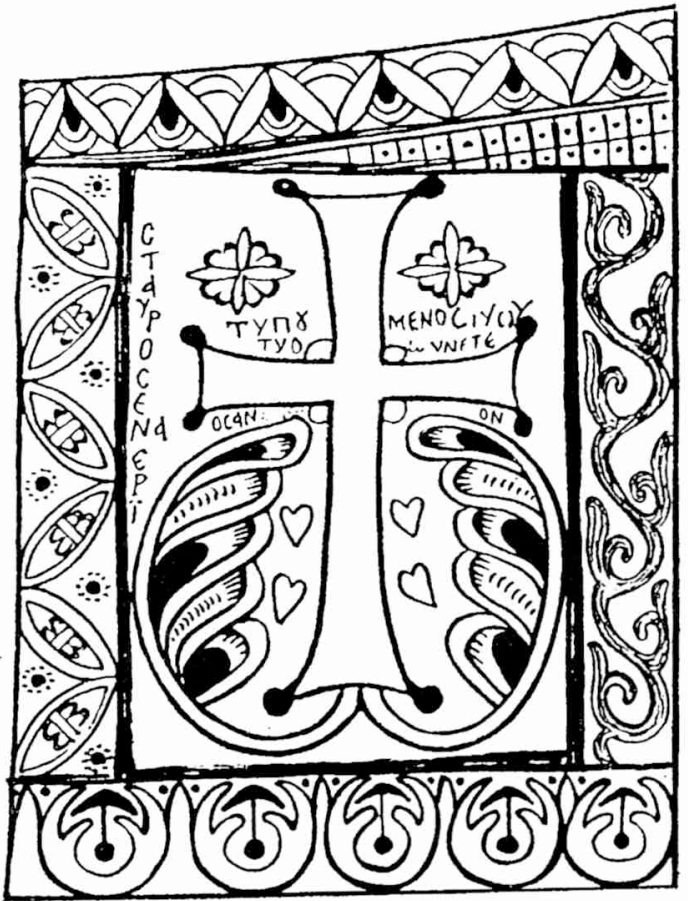

fig. 3. kaplica św. Bazylego, ok. 900 rok, Kapadocja, według: N. Teteriatnikov, The frescoes of the Chapel of St. Basil, rys. 3. 

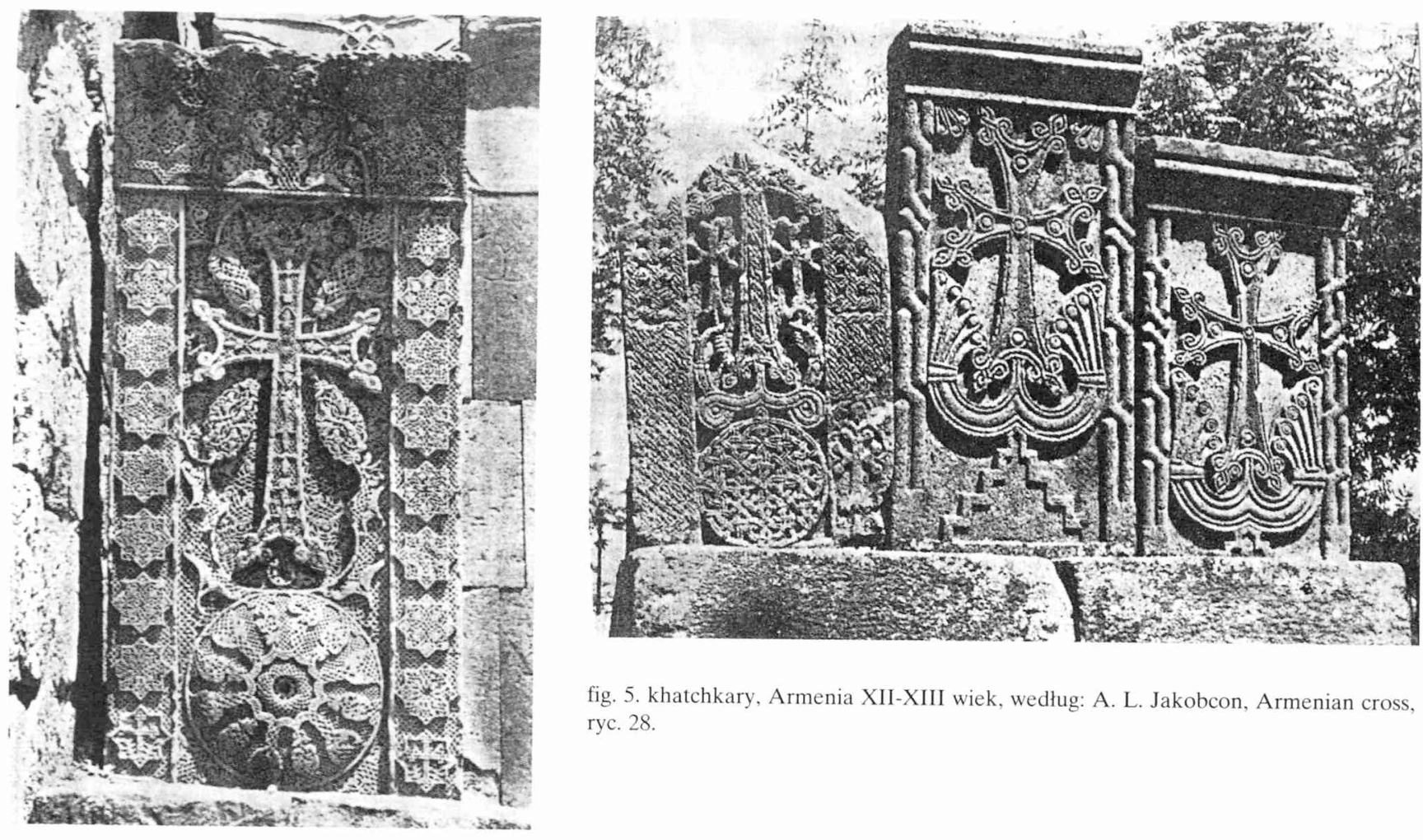

fig. 5. khatchkary, Armenia XII-XIII wiek, według: A. L. Jakobcon, Armenian cross, ryc. 28.

fig. 6. khatchkar, Armenia, XIII wiek, według: A. L. Jakobcon, Armenian cross, ryc. 61. 


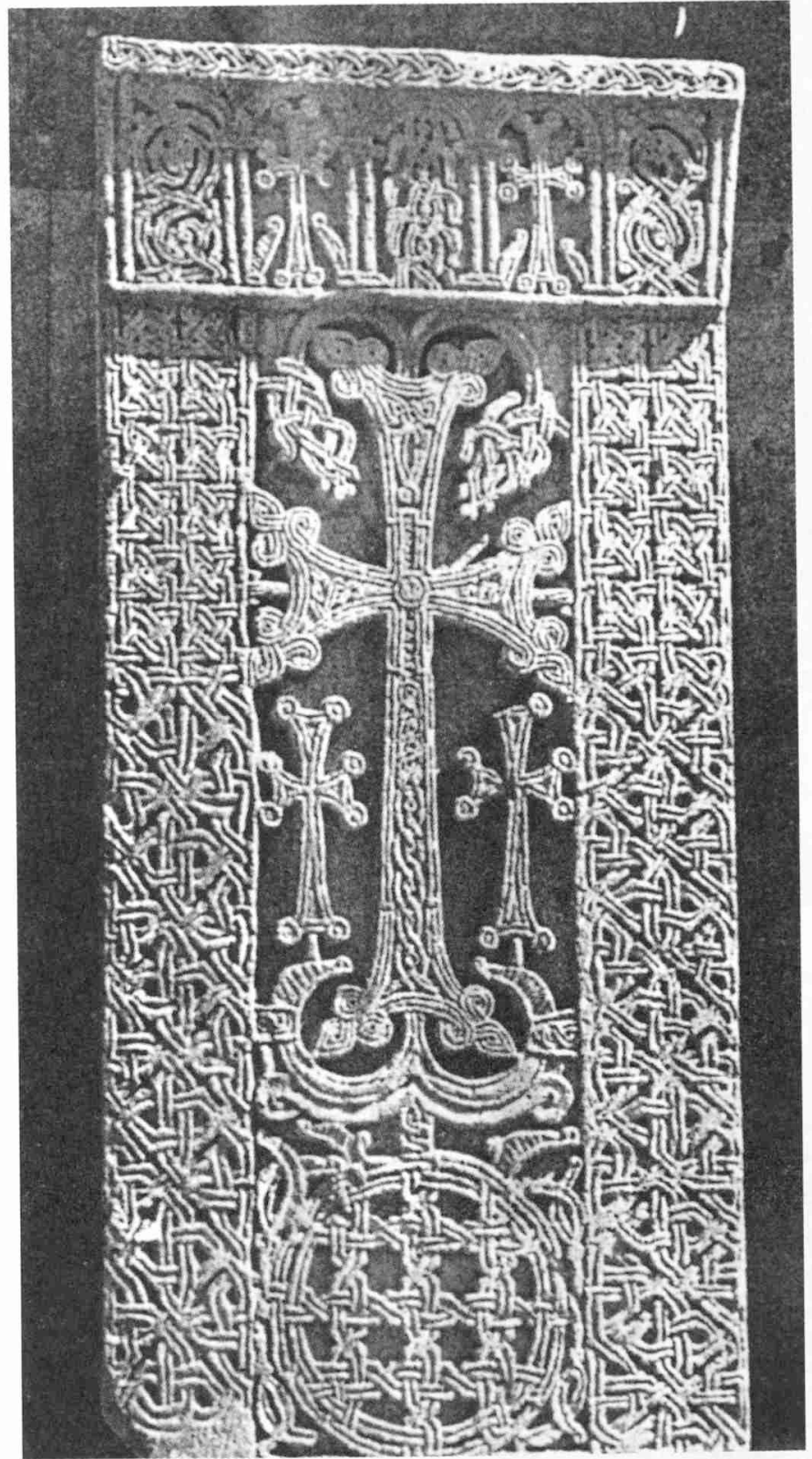

fig. 7. khatchkar, Armenia, XIII wiek, według: A. I. Jakobcon, Armenian cross, ryc. 51 . 